\title{
RadioVolunteer, a novel combination of social, management and technological innovations by the Royal College of Radiologists of Thailand in response to the COVID-19 pandemic
}

\author{
Wiwatana Tanomkiat, M.D. ${ }^{(1)}$ \\ Adisorn Taprig, B.Sc. ${ }^{(2)}$ \\ Nitra Piyavisetpat, M.D. ${ }^{(3)}$ \\ From (1) President, Royal College of Radiologists of Thailand. \\ ${ }^{(2)}$ General Manager, J.F Advance Med Company. \\ ${ }^{(3)}$ Chair, Advisory Committee on Prevention of Communicable Respiratory \\ Infections in Clinical Radiology, Royal College of Radiologists of Thailand. \\ Address correspondence to W.T. (email: twiwadha@hotmail.com)
}

Received 16 August 2021 ; revised 19 August 2021 ; accepted 20 August 2021

doi:10.46475/aseanjr.v22i2.146

\section{Abstract}

RadioVolunteer, a project launched by the Royal College of Radiologists of Thailand, combined social, technological and management innovation, and integrated government, private and non-profit sectors, to overcome a complex task that only one sector could not seamlessly complete. Working on a digital platform which allowed radiologist volunteers from any part of Thailand to promptly read and report chest radiographs of patients with corona virus disease 2019 (COVID-19) who resided in prisons across the country. Its digitized reporting format helped triage patients with COVID-19 pneumonia, and also screen for tuberculosis.

Keywords: Digital intervention, Artificial intelligence, Chest radiograph, Corona virus disease 2019, Tuberculosis, Prison. 


\section{Background}

Associated Professor Nitipatana Chierakul, as the President of Thoracic Society of Thailand under Royal Patronage [1] telephoned one of us (WT), as the President of the Royal College of Radiologists of Thailand (RCRT) [2], on May 15,2021 , to share his great concern regarding the third wave of the COVID-19 pandemic spreading through Thailand. He predicted that superclusters would arise at any time, with prisons as a particularly high-risk location. He suggested that all societies of health professionals in the country should recruit resources, especially human, to be ready to assist. On that day, an author (NP) was asked to run a project under the name of the RCRT which would consist of chest radiology experts, radiologist volunteers, and private sectors which had corporate social responsibility policies. The J.F. Advance Med Co., a radiological digital technology supplier, was chosen to create a digital platform where more than 5,000 chest radiographs a day could be displayed, interpreted, reported, and recorded. This project was named "RadioVolunteer" (Figure 1a) by the author (NP).

\section{Description}

Chest radiology experts were asked to choose a reporting format which would clearly guide caring physicians to the type and intensity of pulmonary involvement, be friendly to the volunteers interpreting radiologists, and understandable to the assisting medical staff and patients. Ramathibodi Hospital's Co-RADS [3] was adapted, simplified and digitized to use in the RadioVolunteer project.

This project was inspired by a prior project, "RT Hero" (Figure 1b), run by the Thai Society of Radiological Technologists to recruit radiological technologist volunteers for COVID-19 field hospitals. However, that project had a few drawbacks, mainly because it used face-to-face operation and volunteers needed to stay near the site. Learning from those lessons, RadioVolunteer strove to allow volunteers to join from any place at their most convenient times. To cover at least the daytime hours, the number of volunteers must be sufficient that even by entering into the system randomly, there would be at least 4-5 volunteers in each hour. 


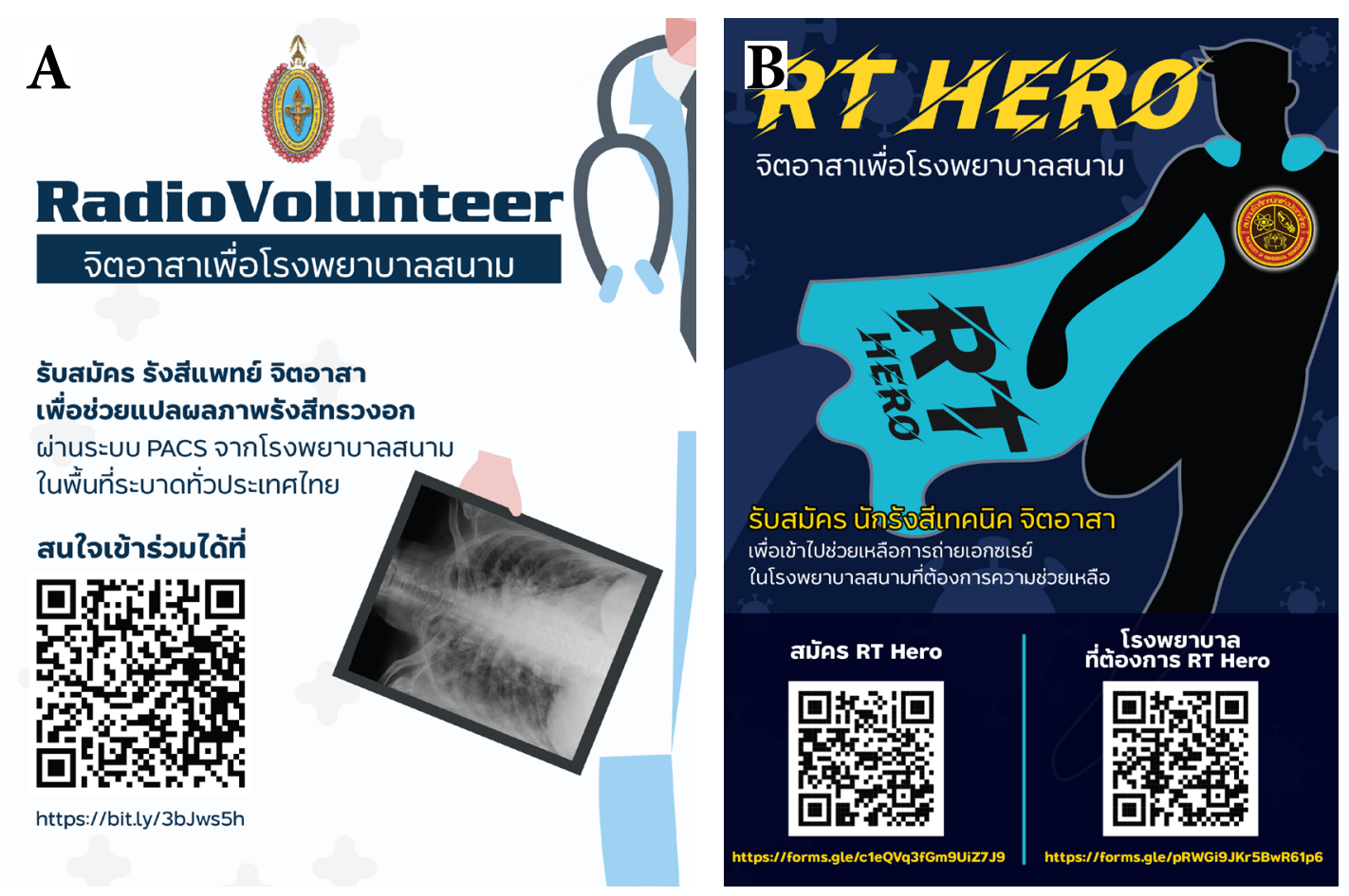

Figure 1. Digital posters for (A) "RadioVolunteer" and (B) "RT Hero" which were disseminated via social media to recruit volunteers.

In addition to the speed of the digital platform system, a friendly and joyful reporting system was also essential. Two authors (NP and AT) designed and created the digital reporting system (Figure 2a) that allowed a normal chest radiograph (CXR) with a good image quality to be displayed, interpreted and reported with 3 clicks. Together with the motto "every click helps save a life", recruitment drew more than 350 board-certified Thai radiologists into the project (Figure 3).

The volunteers interpreted the original CXR image side-by-side with a computer -assisted image assessed by an artificial intelligence (AI) technology provided by the platform (Figure 2b). In this way, the RCRT used RadioVolunteer as a 'sandbox' where members could experience AI, and technology suppliers could introduce AI products to the radiologists. Moreover, the accuracy of AI compared to the volunteer radiologists, and the usefulness of AI to the radiologists or to the diagnostic work flow could all potentially be assessed by the RCRT. 

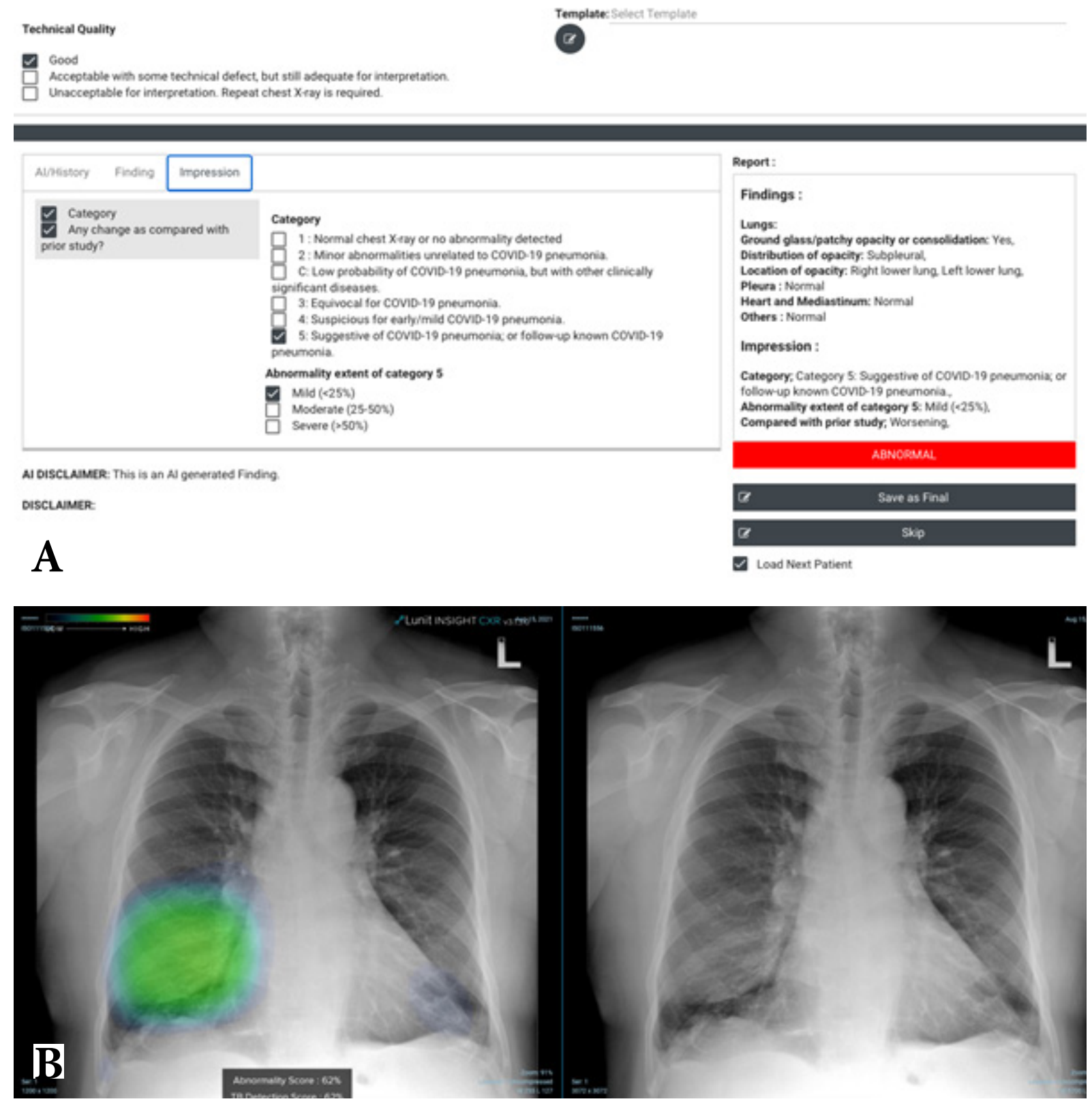

Figure 2. The digital reporting system (A) captures image quality, findings, diagnostic categories, extent of COVID-19 pneumonia, and comparison with prior images. (B) The original chest radiograph is displayed side-by-side with the computer-assisted (AI) one. 


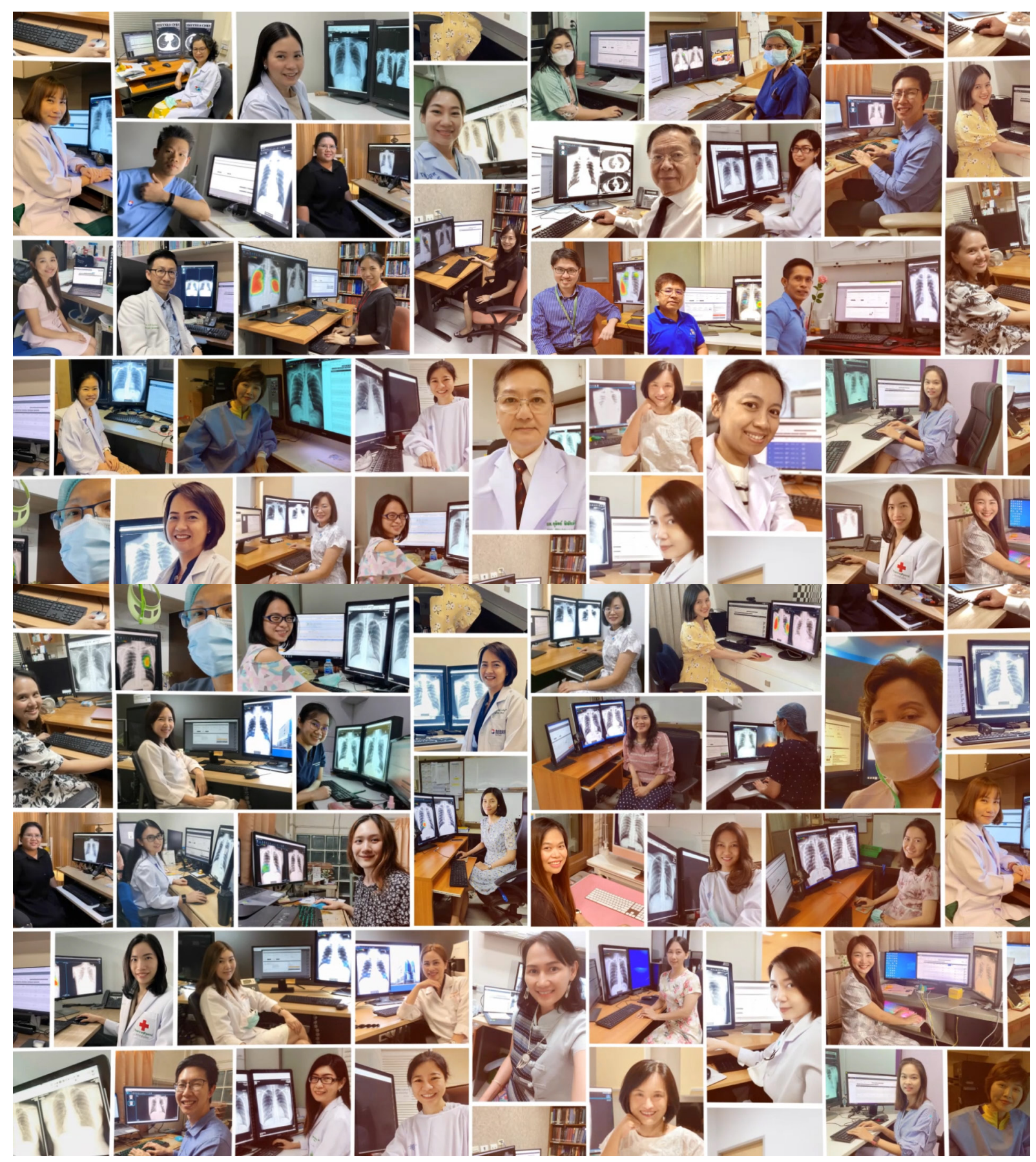

Figure 3. Some of the 350 volunteer radiologists who joined from home and work locations. 
RadioVolunteer was launched on June 2, 2021, and the first volunteers were the authors and other chest radiology experts. The operation was set up in response to a request from the Department of Corrections of Thailand where there was a shortage of radiologists in its hospitals. Reports from radiologists were used for triaging the level of medical care, including anti-viral medication, among infected prisoners (Figure 4). During June-July 2021, 77,037 chest radiographs of infected prisoners in 34 prisons in all parts of Thailand were interpreted by RadioVolunteer. The surprisingly low mortality rate of $0.1 \%$ in the infected prisoners, compared with $0.8 \%$ in the infected general Thai population (though the prisoners may tend to be younger) during the same period of time [4] was thought to be due to the effectiveness of the caring system, including the timely chest radiograph reports from RadioVolunteer.

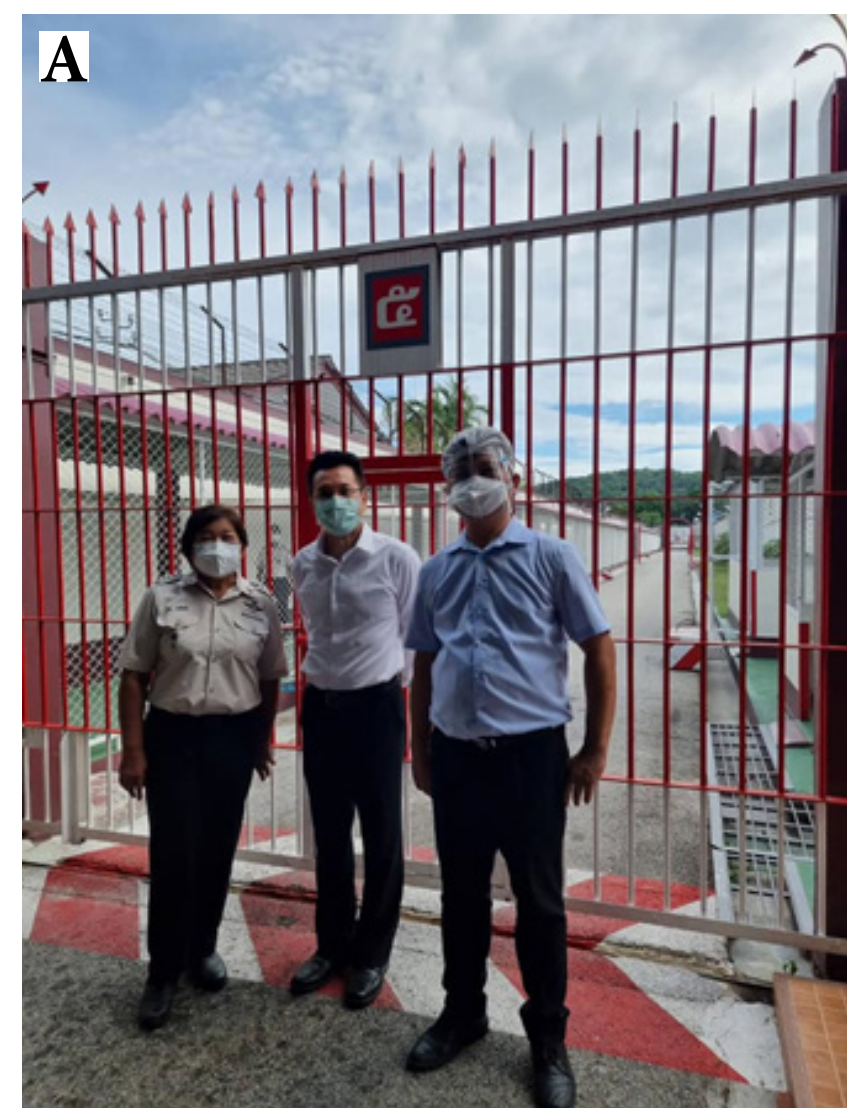

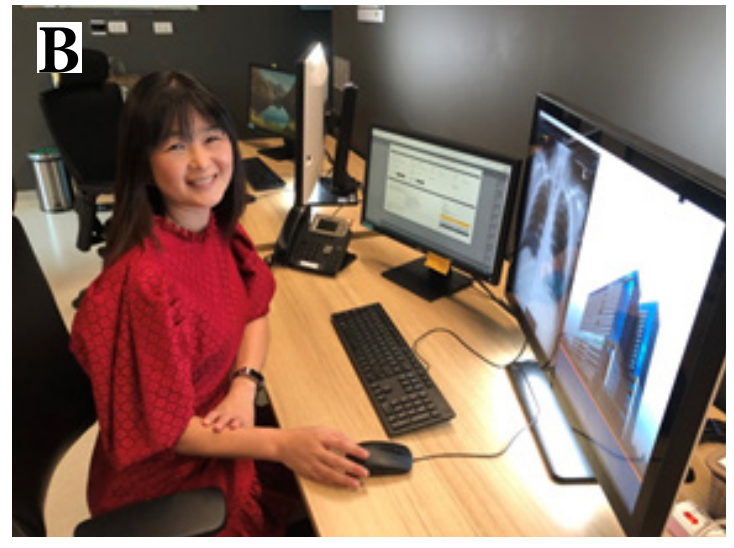

Figure 4. (A) Mrs. Nipha Ngamtrairai, the director of prisons in Songkla, a province in the deep south of Thailand (left) and two of the authors (WT, middle; AT, right) at one of the participating prisons, representing government, non-profit and private sectors, respectively. (B) One author (NP) is interpreting and making a report through RadioVolunteer from her office in Bangkok, more than 1,000 kilometers from the site. 
With an estimated incidence of 153 new cases of tuberculosis (TB) per 100,000 population in 2018, Thailand is among the 12 countries with the highest TB burdens [5]. It is the national policy to end tuberculosis by 2030 to meet the Sustainable Development Goal (SDG), according to the United Nation (UN) [6] and the World Health Organization (WHO) End TB Strategy [7]. One of the five strategies to reduce TB incidence to 88 cases per 100,000 population per year within 2021was to use chest radiography as a screening tool in all people within 7 high-risk groups [8]. Having the highest incidence, prisoners are the first group to be screened. The plan to screen all prisoners with chest radiographs was to begin in March 2021, but was completely stopped in April due to the third wave of COVID-19 which spread to all parts of Thailand, including in prisons. RadioVolunteer, even though initiated to assess COVID-19 pneumonias, also allowed part of the screening TB plan to be implemented because TB, either of active or indeterminate activity, was included in the report format.

From prisons, RadioVolunteer expanded its help to non-prison field hospitals in many parts of Thailand during June-July, 2021. When the COVID-19 infection rate was sky rocking in August, 2021, to over 20,000 new cases per day, forms of medical caring system in addition to field hospitals were initiated. This included community and home isolation for those who were infected and waiting for standard medical care in the hospitals. RadioVolunteer, with an estimated capacity of more than 8,000 CXRs a day and a maximal speed of more than 1,100 CXR images per hour, is ready to plug in with any medical care system which requires chest radiographs to determine extent of pneumonia. 


\section{Discussion}

RadioVolunteer combined social, management and technological innovations, and allowed cooperation of three sectors of society: government, private and non-profit. These sectors shared and integrated their different strengths to execute a complex task that one sector alone could not seamlessly complete. The technological innovations which bridged geographic and time boundaries, provided opportunities to the radiologist volunteers from all parts of the country to conveniently use their professional skills to help patients from all parts of the country. Digital chest radiographs, AI, and a specially-designed digital reporting system were used for triage and directing medical attention to not only COVID-19 pneumonia but also tuberculosis.

Information and communications technology is one (Goal 9) of the SDGs, with the hope that digital technology will enhance the delivery and analysis of information which is essential to achieve other SDGs, including health promotion [6]. RadioVolunteer was a good example of a digital intervention to enhance patient care, surveillance, and management. It was also a good 'sandbox' for introducing, using and examining an AI product. In the future, the RCRT may add other aspects to RadioVolunteer, such as education and skill development.

Acknowlegement: The authors, on behalf of the Royal College of Radiologists of Thailand and RadioVolunteer project, would like to thank the many radiologists who volunteered their time for this project and the staff of the J. F. Advance Med Company for their helpful support. 


\section{References}

1. President talk March 2021 [Internet]. Bangkok: Thoracic Society of Thailand under Royal Patronage; 2021 [cited 2021 August 18]. Available from: https:// www.thoracicsocietythai.org/2021/03/01/\%e0\%b8\%aa\%e0\%b8\%b2\%e0\%b8 \%a3\%e0\%b8\% 88\%e 0\%b 8\%b2\%e0\%b8\% 81\%e0\%b8\%99\%e0\%b $8 \%$ b 2\%e0\%b8\%a2\%e0\%b8\%81\%e0\%b8\%aa\%e0\%b8\%a1\%e0\%b8\%b2\%e0\%b8\%8 4\%e0\%b8\%a1\%e0\%b8\%ad\%e0\%b8\%b8\%e0\%b8\%a3\%e0\%b9\%80\%e0\%b8\%a 7\%e0\%b8\%8a\%e0\%b8\%8a-3/ Thai.

2. Letter from President 20 May 2020 [Internet]. Bangkok: Royal College of Radiologists of Thailand; 2019 [cited 2021 August 18]. Available from: https:// www.rcrt.or.th/the-royal-college-of-radiologists-of-thailand/ letter-form-president/ Thai.

3. Suwatanapongched T, Nitiwarangkul C, Sukkasem W, Phongkitkarun S. Rama Co-RADS: Categorical Assessment Scheme of Chest Radiographic Findings for Diagnosing Pneumonia in Patients With Confirmed COVID-19. Rama Med J [Internet] 2021 [cited 2021 Aug 18];44:50-62. Available from: https:// he02.tci-thaijo.org/index.php/ramajournal/article/view/251259 Thai.

4. สถานการณ์ผู้ติดเชื้อ COVID-19 อัพเดทรายวัน: ข้อมูลเชิงวิเคราะห์รายจังหวัด [อินเตอร์เน็ต]. นนทบุรี:กระทรวง สาธารณสุข; 2564 [เข้าถึงเมื่อ 18 สิงหาคม 2564]. เข้าถึงได้จาก: https://ddc.moph.go.th/covid19dashboard/?dashboard=analysis-province

5. WHO releases new global lists of high-burden countries for TB, HIVassociated TB and drug-resistant TB [Internet]. Geneva: World Health Organization; 2021 [cited 2021 Aug 18] . Available from: https://www.who.int/ news/item/17-06-2021-who-releases-new-global-lists-of-high-burdencountries-for-tb-hiv-associated-tb-and-drug-resistant-tb 
6. Sustainable Development Goals [Internet]. 2015. New York: United Nations. Department of Economic and Social Affairs [cited 2021 Aug 18]. Available from: https://sustainabledevelopment.un.org/sdgs

7. Sixty-seventh World Health Assembly. Resolution WHA67.1. Global strategy and targets for tuberculosis prevention, care and control after 2015 [Internet]. 2014 May 21 [cited 2021Aug 18]. Available from: http://apps.who.int/gb/ ebwha/pdf_files/WHA67/A67_R1-en.pdf

8. Thailand Operational Plan to End Tuberculosis 2017-2021 [Internet]. Ministry of Public Health; 2017 [cited 2021 Aug 18]. Available from: https:// www.tbthailand.org/download/Manual/Thailand\%20Operational $\% 20$ Plan\%20To\%20End\%20\%20TB_2017_2021.pdf 